as to his worthiness for the high office of producing children by her. In brief, marriage and family relations among the Maori were determined by many other social factors besides that of physical fitness.

In substantiation of my remarks I refer the reader to various papers. by Best, Gudgeon and Dr. Goldie in the Transactions of the New Zealand Institute and Polynesian Journal, besides the writings of S. Percy Smith, Judge Wilson and James Cowan, whose statements are fully confirmed by my personal knowledge of the natives in the Waikato and the Urewera districts.

Department of Ethnology,

London School of Economics

(University of London).

\section{Greenland or Polar Front?}

No doubt the gravitational outflow of air from the ice-dome of Greenland is the source of a good deal of cold air to the cyclones of the North Atlantic, as upheld by Prof. Hobbs in his paper to the Geography Section of the British Association at Southampton, and printed in NATURE for October 3. But why, many meteorologists will ask, should he go to the extreme length, implied in the article, of disregarding other sources of cold air for the Bjerknesian mechanism of cyclonic circulation? Can Prof. Hobbs seriously intend that the sloping ice plateau of Greenland, so very limited by comparison in area, can supply all, or nearly all, the cold air for the cyclonic activity of the entire northern hemisphere, Pacific, as well as Atlantic, centre? The idea seems incompatible with the scale of operations, and the facts quoted by Prof. Hobbs himself, if rightly interpreted, show that it really is incompatible. Of course, if Greenland were denuded down to sea-level one spring in the mechanism would be removed, and doubtless important modifications would be imposed upon the characteristic circulation of the North Atlantic Ocean; for in the last resort the details of the atmospheric circulation and the perpetual transpositions of the Polar Front are dominated by geographical configuration, or in other words by continentality and oceanity relationships. But the facts do not warrant the contention that Greenland, in a sense an accidental feature in the circumpolar configuration, is the mainspring of the circulation in the northern hemisphere.

Take the very fact adduced by Prof. Hobbs of the mean barometric pressure over the north polar basin. as established by the late Prof. Mohn, not being inordinately high. This is of little consequence. What is of consequence is the fact that the mean polar pressure is higher than the Atlantic minimum near Iceland and the Pacific minimum in the Bering Sea. This mean or average distribution of pressure means, when translated into day to day changes, that just as warm, humid equatorial air commonly drifts northward, so will cold dry polar air frequently drain southward irrespective whether Greenland is there to reinforce the process or not. This statement is simply in accord with the known laws of wind and pressure distribution, and every modern weather forecaster is familiar with true polar air on his day-today charts.

Then we are told that the air of the polar basin " where rain and fog are common " is not of the right quality to form discontinuities and interact with the equatorial currents in accordance with the admitted Bjerknesian process. Yet what could be farther from the truth than this statement? The north polar basin or Arctic Ocean is in the winter months one of the three "poles of cold" in the northern hemisphere, with a mean January temperature round the Pole, according to Mohn, of $-40^{\circ} \mathrm{F}$. or C., the other two being northeast Siberia and the Greenland ice-dome itself. This extremity of cold over the inner polar basin necessarily implies dry air, and all polar explorers have testified to the sparkling dry atmosphere of the long polar night. The rain and fog occur temporarily and locally in the thaw weather of summer (never in winter except occasionally near Spitsbergen where there is warm Atlantic water); but, even so, outflows of polar air are amply cold and dry enough to interact with the equatorial air to supply the milder cyclonic activity of summer.

It must not be forgotten, further, that in winter the frost-bound continents can constitute additional reservoirs of "polar" air; and this fact is one of the chief, if not the chief, cause of the terrific state of turmoil which the North Atlantic Ocean is commonly in during the months of December and Januarywhen supplies of " polar" air, to interact with warm damp Atlantic equatorial air, may be drawn not only from the North Pole and Greenland, but also from North America and Europe.

Finally, it should be observed that "glacial anticyclones" of the Greenland or Antarctica type are really disembodied systems, and it would surely be better to speak of gravitational cataracts of cold air. But that is another story. L. C. W. Bonacina.

$$
\begin{gathered}
27 \text { Tanza Road, Hampstead, N.W.3. } \\
\text { November } 4 \text {. }
\end{gathered}
$$

\section{Relation of Language to Physiological Stimuli.}

IN examining a vocabulary of more than a thousand words (compiled from upwards of sixty languages) bearing directly or indirectly on the sense of smell, it becomes apparent how many words are vocalisations and articulations of simple reactions to olfactory stimuli. A few examples must suffice here. $[\overline{\mathrm{ch}}=\mathrm{ch}$ in loch, $\overline{\mathrm{ch}}=\mathrm{tch}$.]

A common reaction to odours would be the syllables like $b u, p u, f u, h u, s u, t u$, etc., expressing the idea of blowing, puffing, budding, bulging, etc., and we have, e.g. Persian bu, odour; Efik bu, to rot, and bu-beve, to blaze; Circassian buà gim, sense of smell ; Efate busi, to blow; Malay busuk, putrid; Chinook piu-piu, to stink, also skunk; Tibetan pö, incense; Tahiti puha and Hawaiian puhi, to blow; Samoan puaoa, mist; Inca (Quichua) puhuni, to blow, puhucuni, to kindle, hapuni, to smoulder, puhura, feather, and puyu, cloud; Melanesian punu, smoke; Japanese punpun, like a delicious perfume; Samoan punapuna, to ascend; Russian pwerhnut, to puff, blaze, and pucich, feather. We have the international expressions of disgust, e.g. faugh, pfui, fi, etc. We have fimus, fumus, foetid, and so forth, the Efik word futa, to blow; Chinese $f u$, fragrance; Japanese fuki, to blow (hanafuki=handkerchief), and shuki, stench; Natick Indian shuah, to stink; Basque su, fire and nose; Latin tus and Gaelic tuis, incense; Russian tuman, fog; Melanesian tunga, fire; Zulu tunga, smoke (cf. dung, Dünger, tongue, etc.); Basque tusuri and Tibetan $d \ddot{u}$, devil; Ancient Egyptian $c \bar{h} u a$, to rot; Chinese cheu, stink, and smoke ; and Russian chuyanie, scenting, understanding. Of interest here, too, are the Tibetan $u$, breath, and Honorific Tibetan $=$ head Russian $u m$, mind = reason; the Inca $u m a$, head, and umu, priest; the German Atem, Odem, breath ; Odin, and the sacred $O M$; Ancient Egyptian utu, flowers, unguent; Basque usu, pus; Micmac un, fog, etc.

Another natural vocal reaction to olfactory stimuli, and of course connected with breathing, is a combination of guttural and vowel-sounds and words, perhaps sometimes vocalisation of hawking or vomiting. To 